\title{
BUDAYA LISAN VS BUDAYA LITERASI MAHASIS WA MELAYU: Implikasinya pada Model Pembelajaran Mahasiswa
}

\author{
Agus Syahrani
}

\begin{abstract}
Abstrak
Kajian ini bercermin pada keluhan sebagian mahasiswa yang belum dapat memenuhi tugas dan tanggung jawabnya secara maksimal, khususnya dalam memenuhi tugas-tugas membaca dan menulis. Hal ini diasumsikan berkaitan erat dengan kebiasaan-kebiasaan mahasiswa yang mengakar berkaitan dengan latar belakang sosial budaya mahasiswa yang dominan berlatar belakang budaya Melayu dengan identitas kelisanannya. Merujuk kepada kenyataan dan pemikiran tersebut, penelitian ini bertujuan untuk mengungkapkan kebiasaan-kebiasaan mahasiswa dalam hal kelisanan dan literasi, baik untuk memenuhi keperluan tugas sebagai mahasiswa maupun untuk keperluan-keperluan lain seperti untuk mengisi waktu luang. Teknik pengumpulan data yang digunakan adalah teknik pengamatan langsung oleh peneliti, diskusi melalui Focused Group Discussion (FGD) dan pengamatan tidak langsung melalui angket serta dilengkapi dengan studi kepustakaan. Peroleh data kualitatif dari masing-masing instrumen tersebut dianalisis dan dideskripsikan secara kualitatif.
\end{abstract}

Katakunci: budayalisan, budayaliterasi,modelpembelajaran,mahasiswaMelayu

\begin{abstract}
This study reflects on complaints that some students have not been able to fulfill their duties and responsibilities to the fullest, especially in fulfilling the tasks of reading and writing. It is assumed to be closely related to the habits of the students related to deep-rooted social and cultural backgrounds of students are predominantly Malay cultural background with kelisanannya identity. Referring to the reality and mind, this study aims to reveal the habits of students in terms of orality and literacy, both as a duty to meet the needs of students as well as for other purposes such as for leisure. The data collection technique used is the technique of direct observation by researchers, discussion through Focused Group Discussion (FGD) and observation indirectly through questionnaires and equipped with library research. Qualitative data obtained from each instrument were analyzed and described qualitatively.
\end{abstract}

Keywords : oral culture, cultural literacy, learning model, Malay students 


\section{LATAR BELAKANG}

Mahasiswa di Fakultas Keguruan dan Ilmu Pendidikan (FKIP) Universitas Tanjungpura (Untan) sebagian besar berasal dari berbagai daerah di wilayah Kalimantan Barat. Mereka pada umumnya dapat diidentifikasikan sebagai orang Melayu karena Kalimantan Barat adalah bagian wilayah pulau Kalimantan yang disebut sebagai pulau Melayu (James T. Collin dalam Chairil Effendi, 2006). Tugas rutin mereka sebagai mahasiswa, adalah belajar, yaitu mengikuti perkuliahan secara tatap muka dengan para dosen, praktek laboratorium dan mengerjakan tugas-tugas akademik perkuliahan lainnya, terutama tugas-tugas dan tes-tes dalam bentuk literasi dan selebihnya adalah tugas-tugas dalam bentuk lisan seperti diskusi, presentasi, seminar dan ujian-ujian lisan mata kuliah tertentu serta ujian skripsi.

Dengan demikian, kegiatan mahasiswa sehari-hari tidak dapat dipisahkan dengan kegiatan literasi (literacy), bahkan kegiatan itu sudah sepatutnya menjadi bagian dari karakter pribadi seorang mahasiswa karena kegiatan literasi adalah identik dengan sekolah atau kampus (Kramsch, 2008). Hal ini sesuai dengan beban tugas rutin yang harus dipenuhi oleh mahasiswa, pada umumnya. Kegiatan itu mulai dari yang paling sederhana seperti membaca buku-buku teks, membuat catatan perkuliahan, membuat rangkuman dari hasil bacaan, menjawab soal-soal latihan atau ujian, menulis laporan hasil pengamatan lapangan atau pengamatan laboratorium, menulis paper sampai dengan mengerjakan tugas akhir berbentuk penelitian, dan penulisan laporan penelitian atau skripsi.

Selain itu, sebagai sebuah perguruan tinggi, Untan khususnya FKIP, mempunyai tanggung jawab mengemban tugas Tri Dharma Perguruan Tinggi yang meliputi (1) pendidikan dan pengajaran, (2) penelitian, dan (3) pengabdian kepada masyarakat. Hal ini tidak terlepas dari tuntutan kegiatan literasi bagi sivitas akademika Untan, terutama bagi mahasiswa sebagaimana telah diterangkan di atas. Namun demikian, untuk dapat memenuhi tuntutan itu, bukanlah suatu perkara yang sederhana. Hal tersebut memerlukan pembiasaan kepada mahasiswa dari sejak awal bahkan kebiasaan itu sepatutnya sudah dimulai dari lingkungan rumah atau keluarga atau setidaknya sudah dimulai sejak mereka belajar di tingkat pendidikan sebelumnya.

Sebagaimana telah dikatakan, sebagian besar mahasiswa FKIP Untan adalah dari etnik Melayu. Masyarakat Melayu dapat diidentifikasi berdasarkan bahasa atau dialek yang mereka gunakan. Selain itu, masyarakat Melayu juga dikenal dari latar belakang budaya yang mereka miliki. Salah satu identitas masyarakat Melayu adalah budaya lisan, sebagaimana dikatakan bahwa komunitas etnik Melayu hidup dalam budaya lisan primer (Ong, 1982). Selanjutnya, dikatakan pula bahwa tradisi atau budaya lisan tidak sekadar sebagai ciri khas mereka, melainkan juga sebagai alat untuk mentransfer atau menginternalisasikan nilai-nilai sosial budaya mereka (Chairil Effendy, 2006). Hal ini terlihat dari kebiasaan sehari-hari yang dilakukan oleh masyarakat Melayu pada umumnya yaitu adanya tradisi bercerita atau berdongeng, berpantun, dan bersyair. Meskipun kebiasaan ini sudah mulai terkikis, terutama oleh masyarakat di perkotaan, kebiasaan lisan lainnya masih 
terus berlangsung di kalangan masyarakat itu. Kebiasaan yang dimaksud contohnya adalah mengobrol, bergosip, bergurau atau berdiskusi dalam berbagai peristiwa komunikasi. Dengan kata lain, kegiatan kelisanan ini tidak dapat dipisahkan dari kegiatan kehidupan masyarakat sehari-hari. Bahkan sebagian kegiatan akademik kampus juga menghendaki keterampilan dalam kelisanan ini, misalnya dalam diskusi dan debat ilmiah, seminar, presentasi, dan bahkan dalam ujian lisan atau ujian skripsi.

Dengan demikian, di satu sisi, mahasiswa lahir dan besar dari lingkungan masyarakat dengan budaya lisan yang tak dapat dipisahkan dari kehidupan mereka, termasuk dalam kehidupan kampus. Namun di sisi lain, sebagai civitas akademika atau warga kampus mereka dihadapkan pada sebuah budaya literasi yang juga harus menjadi identitas kepribadian mereka, yaitu untuk membentuk kepribadian yang mandiri, kritis, kreatif, inovatif dan kompetitif (Teeuw, 1994). Terwujudnya budaya literasi di kalangan mahasiswa adalah terpenuhinya semua kegiatan akademik literasi secara maksimal oleh mahasiswa. Namun demikian, pada kenyataannya banyak dosen yang mengeluh akan aktivitas literasi mahasiswa dalam memenuhi tugas-tugas perkuliahan mereka, terutama untuk tugas-tugas mandiri. Hasil yang diperoleh masih belum sepenuhnya sesuai dengan harapan. Sebagai contoh, banyak dosen mengeluhkan keaslian hasil pekerjaan tulisan mahasiswa. Keaslian hasil tugas dari sebagian mahasiswa tersebut masih disangsikan karena kemudahan dalam mengakses bahan-bahan pelajaran dari internet. Keadaan ini memberi peluang kepada sebagian mahasiswa yang kurang bertanggung jawab untuk menghasilkan tugas-tugas atau karya tulis dengan cara pintas iaitu dengan cara mengkopi pekerjaan orang lain persis seperti aslinya tanpa menyebutkan sumber rujukan sebagaimana mestinya. Hal yang terjadi pada akhirnya adalah mereka tidak menghasilkan pekerjaan atau karya mereka sendiri secara original. Demikian juga apabila mereka ditugaskan untuk membaca sekian jumlah buku atau artikel, hanya sedikit mahasiswa yang benar-benar berminat untuk mendapatkan bahan bacaan itu dan membacanya secara tuntas

Berangkat dari keprihatinan ini, diduga bahwa kondisi tersebut berkaitan erat dengan latar belakang sosial budaya mahasiswa dengan identitas kelisanannya. Untuk mengetahui lebih jauh akan hal tersebut, perlu dikaji lebih lanjut faktorfaktor yang menyebabkan belum terwujudnya budaya literasi tersebut secara maksimal dalam kehidupan kampus dengan merujuk kepada aspek-aspek yang berkaitan dengan budaya kelisanan sebagai identitas masyarakat Melayu, yang melekat pada diri mahasiswa tersebut. Oleh sebab itu, kajian ini bertujuan untuk mengungkapkan kebiasaan-kebiasaan mahasiswa dalam hal kelisanan dan literasi, baik untuk memenuhi keperluan tugas sebagai mahasiswa mahupun untuk keperluan-keperluan lain seperti untuk mengisi waktu luang.

\section{KERANGKA KONSEPTUAL}

Fokus kajian ini adalah tentang bagaimana mahasiswa memenuhi tugas rutin mereka sebagai mahasiswa. Tugas-tugas yang dimaksud tidak hanya tugas-tugas 
formal yang dibebankan kepada mahasiswa oleh dosen atau pembimbing, tetapi juga tugas-tugas mandiri sebagai upaya pengembangan diri seorang mahasiswa, baik tugas-tugas yang berkaitan dengan kegiatan kelisanan maupun kegiatan literasi. Dengan demikian, secara umum kajian ini merupakan bagian dari kajian pendidikan dan pembelajaran. Namun demikian, kajian ini juga merupakan bagian dari kajian budaya karena dalam konteks ini pendidikan dikategorikan sebagai bagian dari aktivitas budaya di mana mahasiswa dianggap sebagai subjek dalam pendidikan. Mereka adalah manusia yang secara aktif dapat mengkonstruksi dan merekonstruksi fenomena budaya atau yang dikatakan sebagai agency. Ini disebabkan karena manusia adalah pelaku yang mengatur otak mereka dan bukan sebaliknya (Lantolf, 2007). Mereka adalah pelaku yang mengatur fenomena budaya dan fenomena itu dipengaruhi atau terbentuk oleh aktivitas-aktivitas budaya yang ada, nilai-nilai serta artifak-artefak serta psikologi yang ada (Ratner dalam Panofsky, 2007).

Dalam dunia pendidikan, mahasiswa dipandang sebagai individu-individu yang unik dan berbeda satu dengan yang lainnya. Mereka berbeda berdasarkan latar belakang sosial ekonomi, kebudayaan, gender, proses perkembangan, serta berbeda dalam cara dan kemampuan belajar. Di samping itu, secara sosial budaya, mereka adalah anggota suatu kelompok masyarakat yang berkongsi hal-hal yang sama berupa bahasa, nilai-nilai, tradisi-tradisi, dan cara-cara dalam melakukan sesuatu atau yang biasa disebut dengan memiliki kesamaan budaya. Apabila hampir semua orang berkongsi kebudayaan yang sama itu, kebudayaan itu disebut sebagai mayoritas budaya atau budaya dominan (Cruickshank, et al., 2006). Dengan demikian, masalah pendidikan dalam konteks penelitian ini harus ditinjau dari berbagai disiplin ilmu antara lain psikologi, sosiologi dan ilmu kebudayaan selain ilmu pendidikan itu sendiri. Oleh sebab itu, pada bagian berikut ini akan diuraikan isu-isu yang berkenaan dengan latar belakang sosial budaya mahasiswa. Selain itu akan diuraikan pula hal-hal yang berkenaan dengan budaya Melayu dengan identitas dominan budaya lisannya (oral culture) serta kampus sebagai institusi pendidikan dengan identitas dominan budaya literasinya (literate culure). Berikutnya adalah pembahasan mengenai pilihan strategi atau model pembelajaran yang dapat mengakomodasi aktivitas kelisanan dan literasi sebagai representasi dari kedua budaya tersebut.

\section{Latar Belakang Sosial Budaya dan Psikologis Mahasiswa}

Sebagaimana telah banyak dibuktikan bahwa keberhasilan atau kegagalan mahasiswa dalam belajar adalah berhubung kait dengan latar belakang psikologis, sosial dan budaya mereka. Oleh sebab itu, untuk menjadi seorang pendidik yang sukses, ia seharusnya mengetahui latar belakang sosial budaya para peserta didiknya di samping latar belakang psikologis mereka. Secara psikologis, peserta didik dapat dibedakan berdasarkan tingkat usia serta variabel-variabel lain seperti bakat, kepribadian, gaya belajar, tingkat kemampuan bahasa dan motivasi (Harmer, 2004). Kategorisasi ini menjadi penanda seperti apa peserta didik yang 
mereka hadapi sehingga dengan demikian tugas-tugas belajar yang sesuai dapat dikembangkan oleh sang pendidik itu.

Dalam pada itu, dari latar belakang sosial budaya, peserta didik dapat diidentifikasikan berdasarkan asal usul kelompok sosial atau kelompok etnik atau ras tertentu. Dalam kaitan ini, mereka dapat diidentifikasikan berdasarkan hal-hal yang mereka kongsi bersama, misalnya bahasa yang digunakan, nilai-nilai, tradisi-tradisi dan cara-cara melakukan sesuatu. Hal-hal tersebut disebut dengan kebudayaan mayoritas. Namun demikian, kebudayaan mayoritas tersebut tidak berarti harus berlaku sama rata bagi setiap individu dari kelompok tersebut, melainkan biasanya terdapat sub-sub budaya yang menjadi minoritas (Cruickshank, et al., 2006).

\section{Kelompok Etnik Melayu sebagai Mayoritas dengan Identitas Budaya Lisan}

Profil mahasiswa FKIP Untan dapat diidentifikasi berdasarkan daerah asal mereka. Mayoritas, mereka berasal dari berbagai pelosok wilayah Kalimantan Barat. Sebagaimana dikenali bahwa masyarakat Kalimantan Barat secara dominan adalah dari kelompok etnik Melayu (54,20\%), urutan berikutnya adalah kelompok etnik Dayak $(33,42 \%)$ dan sisanya adalah dari kelompok etnik Cina, Bugis, Jawa dan beberapa kelompok etnik lainnya (Bakran Suni, 2009). Oleh sebab itu, hampir dapat dipastikan bahwa mayoritas mahasiswa FKIP Untan adalah berlatar belakang sosial budaya etnik Melayu. Dengan demikian, mereka mestinya berkongsi lebih kurang nilai-nilai dan budaya yang sama, berbahasa yang sama meskipun dengan berbagai variasi dialek dan pada umumnya beragama Islam (Suwardi MS, 2008). Kesamaan perkongsian tersebut merupakan identitas orang Melayu pada umumnya

Selain itu, dikatakan pula bahwa masyarakat Kalimantan Barat, khususnya orang-orang Melayu, hidup dalam kelisanan primer (primary orality). Ini berarti bahwa keseluruhan proses mentransfer dan menginternalisasi nilai-nilai sosial budaya dari generasi ke generasi dalam masyarakat itu disampaikan melalui tuturan lisan (Chairil Effendy, 2006). Tuturan lisan tersebut dikenal dengan tradisitradisi berpantun, bersyair, berdongeng, penggunaan ungkapan-ungkapan atau kata-kata bijak (proverbs) serta petatah-petitih sebagai kegiatan rutin masyarakat atau sebagai ritual-ritual tertentu (Teeuw, 1994). Bahkan untuk tujuan komunikasi sehari-hari lainnya-menyampaikan undangan, menginformasikan sesuatu, bertukar pikiran, memberikan empati, atau menyampaikan bela sungkawa - pada umumnya lebih disukai atau lebih diterima dengan cara menyampaikannya secara lisan dan langsung tatap muka. Hal yang demikian itu bertujuan untuk memelihara kesantunan dan untuk mempererat jalinan hubungan di antara mereka (Ong, 1982). Dalam kaitan ini, dikatakan bahwa apa yang disampaikan secara langsung dengan lisan di antara mereka melalui kata-kata itu merupakan penanda social deixis. Penanda itu tidak hanya dapat menunjukkan kapan dan dimana posisi pembicara berada pada saat itu tetapi juga menunjukkan status di dalam struktur sosial yang ada di antara pihak-pihak yang berkomunikasi itu (Kramsch, 2008). Dengan demikian komunikasi lisan menunjukkan makna-makna sosial tertentu bagi masyarakat tersebut. 
Meskipun perkembangan pengetahuan dan teknologi begitu pesat, budaya lisan belum sepenuhnya dapat tergantikan oleh budaya literasi (literacy). Bahkan hadirnya media komunikasi seperti televisi, telepon, internet, dan peralatan komunikasi elektronik lainnya hanyalah memperbaharui kelisanan yang ada atau yang disebut dengan secondary orality (Ong, 1982; Teeuw, 1994). Dengan demikian, kehidupan masyarakat Melayu masih terikat erat oleh aktivitas kelisanan.

\section{Kampus sebagai Lembaga Pendidikan dengan Identitas Budaya Literasi}

Sekolah atau kampus adalah sebuah institusi pendidikan yang memiliki aturan-aturan yang dapat mengatur mahasiswa serta unsur-unsur sivitas akademika lainnya untuk bertindak dan berperilaku sesuai aturan itu. Sebagai suatu lembaga pendidikan tinggi, sebuah universitas atau perguruan tinggi merupakan sebuah organisasi struktural yang memiliki tanggung jawab untuk membangun dan mengembangkan ilmu pengetahuan dan teknologi. Tanggung jawab ini berimplikasi pada tugas-tugas mendidik, mendapatkan temuan-temuan baru, konseptualisasi, menyebarkan dan menerapkan ilmu dan teknologi dalam kehidupan sosial masyarakat (Moelijarto dalam Suwardi MS, 2008).

Dari perspektif antropologi dan sosiologi, institusi pendidikan termasuk salah satu institusi sosial. Institusi ini merupakan sistem yang dapat menjadikan paratisipan yang berada di sana untuk saling berinteraksi berdasarkan polapola formal atau sistem tentang bagaimana berperilaku atau bertindak dan berkomunikasi dengan aktivitas-aktivitas yang terkonsentrasi untuk memenuhi kebutuhan-kebutuhan dalam kehidupan sosial (Kuntjaraningrat, 1979). Lebih lanjut, Gillin dan Gillin (dalam Sudarso, 2007) mengatakan bahwa institusi sosial memiliki beberapa karakteristik, di antaranya adalah memiliki tujuan yang harus dicapai, dilengkapi dengan prasarana dan sarana untuk memfasilitasi pencapaian tujuan tersebut dan memiliki dokumen-dokumen tertulis sebagai referensi yang dirujuk dalam melaksanakan proses pencapaian tujuan tersebut.

Sebagai sebuah institusi sosial, salah satu ciri-ciri khas sekolah atau perguruan tinggi adalah memiliki peraturan perundang-undangan tertulis sebagai rujukan dalam mengatur peran mahasiswa, peran staf pengajar dan staf-staf lainnya serta seluruh elemen yang ada dalam institusi tersebut. Salah satu dari dokumen rujukan tersebut adalah kurikulum. Selain itu, sekolah atau perguruan tinggi juga dilengkapi dengan berbagai bentuk sarana, baik berupa perangkat keras maupun perangkat lunak, untuk menunjang ketercapaian tujuan nya. Salah satu sarana yang paling penting adalah ruang-ruang belajar dan perpustakaan. Perpustakaan ini biasanya menyediakan sumber-sumber berbentuk cetakan atau non-cetakan (elektronik). Belakangan ini sarana perpustakaan juga dilengkapi dengan akses internet. Sarana lainnya adalah berbagai-bagai jenis laboratorium. Semua sarana ini memfasilitasi civitas akademika perguruan tinggi untuk melakukan aktivitas literasi dan komunikasi lisan, baik secara langsung tatap muka maupun tidak langsung.

Berdasarkan ciri-ciri khas perguruan tinggi tersebut, aktivitas literasi (literacy) menjadi dominasi aktivitas akademik kampus, sebagaimana dikatakan berikut ini: 
... while the written medium has been viewed as potentially more subversive than spoken medium, in reality it has also been constrained by institutions like the academy, the law, the publishing industry, that have always been in control of new technologies. The academic monopoly over the meaning of written texts has manifested itself up to recently by its definition of literacy as merely the ability to read and write.

(Kramsch, 2008: 55)

Dengan demikian, representasi budaya tekstual atau budaya literasi dalam aktivitas akademik berbentuk kegiatan membaca, menulis dan presentasi lisan berdasarkan teks merupakan rutinitas yang harus dilakukan oleh seluruh warga kampus, terutama oleh mahasiswa dan staf pengajar.

Meskipun secara historis budaya literasi (literacy) telah ditemukan sejak 3000 SM dan sejak itu telah mengubah budaya lisan menjadi budaya tekstual, pada kenyataannya orang Indonesia, khususnya orang Melayu, masih berada dalam dilema di antara kedua budaya ini (Teew, 1994). Di satu sisi, budaya lisan telah begitu dalam mengakar bagi orang Melayu karena budaya itu disepakati memiliki nilainilai positif yaitu nilai-nilai solidaitas, kebersamaan, dan nasionalisme. Di sisi lain, tuntutan budaya literasi juga harus diikuti, terutama bagi pelajar atau mahasiswa. Hal ini penting demi memenuhi tuntutan perkembangan ilmu dan teknologi serta untuk membangun kepribadian dengan ciri-ciri mampu berfikir logis, kritis dan kreatif sebagaimana layaknya kepribadian seorang ilmuwan.

Dalam pada itu, mengutip pernyataan Sweeney, lebih lanjut Teew mengatakan pula bahwa dilema ini juga terjadi di kalangan pelajar-pelajar Melayu di Malaysia. Dalam memenuhi tugas-tugas tulis yang diberikan, pelajar-pelajar itu menghasilkan tulisan-tulisan yang sesungguhnya lebih merupakan produksi kelisanan (oral orientation). Permasalahan yang sama juga terjadi di kalangan mahasiswa di banyak universitas di Indonesia, dimana ditemukan bahwa kuantitas dan kualitas produk tulisan ilmiah yang mereka hasilkan masih jauh dari apa yang diharapkan dibandingkan dengan hasil-hasil tulisan dari universitas-universitas di negaranegara maju (Suwardi MS, 2008). Dengan demikian, para pendidik bertanggung jawab untuk terus mengembangkan budaya literasi bagi mahasiswa karena budaya ini mengimplikasikan nilai-nilai pribadi terpelajar, cerdas, berfikir logis dan kritis serta kreatif di kalangan mahasiswa, terutama bagi mereka yang berasal dari kelompok etnik Melayu yang sangat terikat dengan budaya lisan. Bagaimanapun, karena budaya lisan ini disepakati memiliki nilai-nilai positif bagi kehidupan sosial mereka adalah bijaksana apabila keduanya dapat diakomodasi secara bersamaan sehingga dapat membentuk kepribadian ilmuwan bagi mahasiswa yang aktif membaca dan produktif menghasilkan karya-karya ilmiah dan juga aktif dalam aktivitas-aktivitas kelisanan ilmiah.

\section{Budaya Lisan dan Budaya Literasi dalam Proses Pembelajaran}

Perkembangan paradigma pembelajaran belakangan ini adalah pembelajaran yang terpusat pada pebelajar, iaitu pembelajaran yang mampu menciptakan 
keperluan atau pengalaman pebelajar menjadi sentral dalam proses pembelajaran. Konsekuensinya adalah bahwa pembelajaran yang baik adalah bukan karena performa guru melainkan bagaimana aktivitas pebelajar dapat terwujud. Dalam hal ini guru atau pengajar hanya berperan sebagai fasilitator dan sebagai sumber inspirasi bagi siswa/mahasiswa (Harmer, 2001).

Sebagaimana telah disebutkan, perguruan tinggi merupakan sebuah institusi pendidikan. Institusi ini berfungsi untuk menginternalisasikan moral dan nilai-nilai serta mengatur apa yang seharusnya dilakukan dan apa yang tidak seharusnya dilakukan oleh para civitas akademika yang ada. Berkaitan dengan ini, staf pengajar adalah salah satu elemen yang berperan sebagai agen atau fihak yang bertanggungjawab membentuk kebiasaan-kebiasaan atau perilaku baik atau ideal pada mahasiswa sebagaimana yang diharapkan. Berkaitan dengan dilema mahasiswa dalam dua budaya yang bertentangan sudah sepatutnya ada tindakan berupa mediasi oleh fihak pengajar untuk mengakomodasi kedua budaya tersebut sehingga keduanya bukan menjadi tantangan melainkan peluang untuk tumbuhkembang demi membangun kepribadian ilmuwan mahasiswa sebagaimana yang diharapkan. Menurut Vygotsky (dalam Rod Ellis, 2009) mediasi dapat berlangsung dalam tiga cara: (1) dengan menggunakan peralatan materi; (2) melalui interaksi dengan orang lain; dan (3) dengan menggunakan simbol-simbol seperti bahasa. Berkenaan dengan ini, selain pengajar itu sendiri dapat menjadi role model dalam pembentukan budaya kampus, mereka juga harus mampu mendesain pembelajaran yang dapat mengakomodasi aktivitas-aktivitas pembelajaran yang merepresentasikan kedua budaya, lisan dan literasi, secara bersamaan.

Untuk memediasi kedua budaya yang saling bertentangan tersebut sehingga menjadi peluang pembentukan budaya keilmuan yang positif bagi mahasiswa diperlukan strategi atau model pembelajaran yang relevan. Dalam kaitan ini, salah satu pendekatan yang dapat direkomendasikan adalah Pembelajaran Kontekstual (Contextual Teaching and Learning), selanjutnya disingkat CTL. Sebagai suatu sistem pendidikan yang holistik, CTL relevan untuk direkomendasikan dalam rangka mengakomodasi budaya lisan yang melatarbelakangi mahasiswa dan sekali gus dalam rangka pembentukan atau pengembangan budaya literasi di kalangan mereka.

MengapaCTL?Jawabnya adalah karenaCTL dikenal sebagai proses pendidikan yang bertujuan membantu pebelajar untuk dapat menemukan makna dalam materi pembelajaran yang mereka pelajari dengan cara menghubungkan materi tersebut dengan konteks kehidupan sehari-hari, termasuk konteks kepribadian mereka dan konteks lingkungan sosial budaya mereka. CTL terdiri dari delapan komponen: (1) membuat hubungan yang bermakna, (2) melakukan pekerjaan yang berarti, (3) belajar mengatur diri sendiri, (4) bekerjasama, (5) berfikir kritis dan kreatif, (6) memperhatikan setiap individu, (7) mencapai standard yang tinggi, (8) menggunakan penilaian yang autentik. Melalui semua komponen tersebut, CTL memberikan lebih dari sekadar bimbingan kepada pebelajar untuk mengikuti atau mempelajari materi sesuai konteks lingkungan mereka. Lebih jauh, CTL juga 
mendorong pebelajar untuk berfikir bahwa manusia memiliki kemampuan dan tanggung jawab, mempengaruhi dan membentuk arah dari konteks yang beragam, mulai dari konteks keluarga, ruang kelas, kelompok, tempat bekerja, lingkungan ketetanggaan, lingkungan komunitas yang lebih luas sampai kepada ekosistem (Johnson, 2002).

Sebenarnya CTL bukanlah sesuatu yang baru. Pendekatan ini sudah cukup populer di kalangan pengajar dalam pelbagai bidang ilmu. Hanya saja penerapannya selama ini masih terfokus kepada usaha untuk pencapaian nilai-nilai angka sematamata sebagai produk pembelajaran, tanpa menyadari pentingnya proses. Padahal proses ini dapat menunjang pencapaian pembentukan karakter sebagai dampak ikutan yang sesungguhnya dapat terwujud melalui penerapan pendekatan ini.

Lebih lanjut, Johnson mengatakan bahwa CTL memberi peluang kepada pengajar untuk dapat mengkombinasikan perkuliahan, wawasan pebelajar, dan projek-projek yang dikerjakan, untuk mencapai sesuatu yang tidak hanya berkaitan dengan ruang kelas tetapi juga sesuatu yang jauh dari luar ruang kelas. Melalui semua rangkaian itu, semua kegiatan belajar-termasuk membaca, menulis dan berbicara serta mendengarkan - secara otomatis harus diterapkan selama proses pembelajaran. Berikut ini adalah contoh-contoh yang menjelaskan bagaimana CTL menghubungkan pokok bahasan akademik dengan konteks lingkungan pembelajar itu sendiri, mulai dari pembelajar di tingkat sekolah dasar sampai dengan tingkat perguruan tinggi:

1. In an Upward Bound class, the teacher encourages students to read, write, and think critically by asking them to focus on controversial issues in the neighborhood or community. The class is divided into groups of four or five. Each group chooses a controversial issue and researches it. They do library research, conduct an on-the-street survey, and interview local authorities on the subject. They assemble their findings into an oral presentation accompanied by photographs, drawings, charts and graphs. They deliver their findings to an audience and parents.

2. A standard CTL approach for studying literature is to formulate one question for students to discuss before they read the assignment. The question deals with an idea or situation students will encounter in the assigned reading. Talking in advance about these ideas paves the way for students to see that literature pertains to them. If they then read the text carefully, becoming familiar with the material, they are ready to apply things they learn in a poem, short story, or essay to the context of daily life.

(Lihat Johnson (2002: 52-55).

Dari contoh yang diilustrasikan di atas, jelaslah bahwa pendekatan CTL dapat memfasilitasi atau mengakomodasi aktivitas kelisanan dan literasi secara bersamaan. Apabila ini diterapkan dalam proses pembelajaran di perguruan tinggi, akan membuat mahasiswa terbiasa dengan kegiatan kelisanan akademik dan budaya literasi. Melalui proses demikian secara terus berkelanjutan mahasiswa akan tetap dapat mengekalkan nilai-nilai yang sebelumnya selalu mereka kongsi dari budaya kelisanan yaitu kebersamaan atau kerja sama, solidaritas dan saling ketergantungan. Bersamaan dengan itu, dengan sendirinya mereka dapat 
membangun budaya literasi sebagai representasi dari budaya keilmuan yang senantiasa mengembangkan nilai-nilai penuh inisiatif, kemandirian, berfikir logis, kritis, dan inovatif serta berdaya saing.

\section{METODE PENELITIAN}

Penelitian ini adalah penelitian deskriptif kualitatif dengan fokus kajian pada pendidikan atau pembelajaran yang ditinjau dari perspektif kebudayaan. Oleh sebab itu metode yang digunakan adalah metode kualitatif dari budaya etnografer dalam mempelajari kebudayaan suatu kelompok masyarakat. Untuk itu, beberapa teknik pengumpulan data yang relevan akan digunakan. Berikut ini akan dijelaskan tentang subjek penelitian yang akan dipilih serta teknik-teknik dan instrumeninstrumen yang digunakan dalam penelitian ini.

\section{Subjek Penelitian}

Subjek yang diambil dalam penelitian ini adalah 100 orang mahasiswa FKIP Untan. Jumlah tersebut diambil dari empat jurusan yang berbeda yang ada di lingkungan FKIP yaitu Jurusan Pendidikan Bahasa dan Seni (PBS), Jurusan Pendidikan Ilmu Pengetahuan Sosial (PIPS), Jurusan Pendidikan Pendidikan Matematika dan Ilmu Pengetahuan Alam (PMIPA) dan Jurusan Pendidikan Guru Sekolah Dasar (PGSD). Dari masing-masing jurusan tersebut diambil sebanyak 25 orang. Subjek yang dipilih adalah mereka yang berlatar belakang etnik Melayu. Yang dimaksudkan dengan kelompok etnik Melayu dalam konteks penelitian ini adalah mereka yang berkongsi budaya lisan dan berbahasa Melayu dengan berbagai-bagai variasi dialek yang digunakan di berbagai-bagai wilayah Kalimantan Barat.

Selain berdasarkan kriteria identitas tersebut, kriteria lainnya adalah tingkatan semester mahasiswa. Untuk itu, mereka yang dipilih adalah mereka yang sudah belajar di FKIP sedikitnya lima semester. Jumlah tersebut akan dipilih secara cluster random sampling. Dengan cara demikian, jumlah 100 orang tersebut dianggap cukup mewakili mahasiswa yang berlatar belakang etnik Melayu dengan ciri-ciri identitas tersebut. Selanjutnya, dari masing-masing kelompok tersebut akan dipilih secara random 10 orang di antara mereka untuk diundang berdiskusi atau urun pengalaman dengan menggunakan teknik Focused Group Discussion (FGD).

\section{Teknik dan Alat pengumpulan Data}

Sebagaimana dikatakan bahwa penelitian adalah penelitian deskriptif kualitatif yang mengadopsi cara-cara atau teknik-teknik yang biasa digunakan oleh etnografer dalam mempelajari kebudayaan suatu komunitas. Oleh sebab itu, data yang akan diperoleh adalah data kualitatif tentang kegiatan kelisanan dan literasi mahasiswa di dalam dan di luar kampus, baik untuk memenuhi tugas-tugas perkuliahan maupun untuk kepentingan lain-lainnya. Adapun teknik-teknik yang digunakan antara lain adalah observasi partisipan yang dilakukan untuk mengamati kegiatan kelisanan dan literasi di sekitar lingkungan kampus. Kemudian untuk memperoleh data yang tidak terjangkau oleh pengamatan langsung tersebut, akan dilakukan 
melalui pemberian kuesioner kepada semua responden dari keseluruhan jumlah subjek penelitian yang dipilih. Selain itu, juga akan digunakan trianggulasi untuk memberikan reliabilitas data melalui diskusi kelompok dengan teknik Focused Group Discussion (FGD) dengan sebagian responden. Diskusi ini akan berlangsung berdasarkan pertanyaan-pertanyaan arahan oleh pemandu diskusi.

\section{HASIL ANALISA DATA}

Sebagaimana telah dikemukakan sebelumnya, analisis data dilakukan berdasarkan jenis data yang diperoleh melalui beberapa jenis instrumen yang digunakan dalam penelitian ini yaitu catatan lapangan, pemberian kuesioner dan rekaman hasil Focused Group Discussion (FGD). Oleh sebab itu, data yang akan diuraikan berikut ini adalah mengikuti urutan tingkat keutamaan data tersebut.

\section{Hasil Pengamatan Terlibat}

Berdasarkan hasil pengamatan terlibat mengenai kegiatan mahasiswa di dalam kampus dapat dikemukakan beberapa gambaran tentang kegiatan mahasiswa pada umumnya. Aktivitas mahasiswa di kampus FKIP Untan selain untuk memenuhi ketentuan-ketentuan yang telah ditetapkan oleh lembaga ini juga untuk memenuhi beberapa kepentingan pribadi mahasiswa. Hal ini terkait dengan fasilitas yang tersedia di lingkungan kampus tersebut. Sebagaimana fasilitas kampus pada umumnya, kampus FKIP menyediakan ruang-ruang kelas untuk aktivitas belajar mengajar konvensional. Selain itu, terdapat pula laboratorium bagi masing-masing program studi yang ada sebagai penunjang program pembelajaran di ruang kelas. Fasilitas lainnya adalah perpustakaan atau ruang referensi. Sementara itu terdapat pula fasilitas penunjang lainnya yaitu ruang-ruang terbuka, taman-taman, tempat ibadah (mesjid), tempat parkir kendaraan dan kantin-kantin serta ruang-ruang kegiatan kemahasiswaan. Jaringan internet juga tersedia dan dapat diakses oleh mahasiswa untuk menunjang aktivitas perkuliahan dan keperluan pribadi mereka. Fasilitas-fasilitas tersebut dapat menciptakan aktivitas kelisanan dan literasi mahasiswa.

Aktivitas utama yang dilakukan oleh mahasiswa di dalam ruang kelas adalah untuk mengikuti kegiatan formal perkuliahan secara konvensional tatap muka dengan dosen. Ketika jam perkuliahan usai, pada umumnya mereka segera meninggalkan ruang kelas. Meskipun kadang-kadang beberapa orang mahasiswa memilih tetap tinggal di ruang kelas sambil menunggu perkuliahan selanjutnya atau sekedar beristirahat sambil berbincang-bincang atau bergurau dengan satu atau dua orang teman sekelas. Kadang-kadang dijumpai pula bahwa beberapa di antara mereka terlihat tekun bekerja dengan laptop masing-masing di ruang kelas itu, terutama di ruang-ruang kelas di mana mereka dapat mengakses internet.

Selain di ruang kelas, aktivitas perkuliahan juga dilakukan di ruang-ruang laboratorium. Aktivitas di ruang-ruang laboratorium ini pada umumnya adalah berkaitan dengan kegiatan perkuliahan formal yaitu sesuai dengan jadwal yang telah ditentukan oleh program studi atau dosen yang bersangkutan, baik dalam 
kegiatan klasikal atau kelompok. Adapun kegiatan laboratorium ini bergantung kepada jenis laboratorium itu sendiri atau sesuai dengan program studi masingmasing. Aktivitas perkuliahan formal baik di ruang kelas maupun di laboratorium selalu melibatkan kegiatan kelisanan dan literasi yang bersifat wajib.

Sementara itu, aktivitas lainnya adalah aktivitas yang bersifat manasuka (pilihan), seprti mengunjungi perpustakaan atau ruang baca. Aktivitas di ruang ini lebih didominasi oleh kegiatan literasi karena terdapat larangan untuk berbicara di ruang perpustakaan. Karena ketersediaan fastilitas penunjang perpustakaan yang masih sangat terbatas, hanya sebagian kecil mahasiswa yang memanfaatkan fasilitas ini untuk aktivitas membaca atau menulis.

Selain fasilitas-fasilitas tersebut di atas, fasilitas lain sebagai tempat favorit bagi mahasiswa untuk menghabiskan waktu mereka di kampus adalah di tamantaman atau di ruang terbuka di sekitar kampus. Di tempat-tempat ini mereka juga sering terlihat melakukan aktivitas kelisanan dan literasi. Fasilitas lain yang sangat diminati dan dibutuhkan adalah kantin kampus. Tempat ini tidak sekedar tempat untuk menikmati makanan tetapi juga untuk melepaskan lelah, berkumpul dengan sesama teman, berbincang-bincang, bergurau dan kadang-kadang sambil membuka laptop dengan akses internet. Dengan demikian, kantin juga tempat yang memungkinkan untuk aktivitas kelisanan dan literasi.

\section{Hasil Kuesioner}

Untuk melengkapi deskripsi tentang aktivitas mahasiswa dalam hal kelisanan dan literasi baik di dalam lingkungan kampus maupun di luar kampus, berikut ini dapat dikemukakan data yang lebih rinci yang diperoleh dari hasil isian kuesioner oleh responden (mahasiswa), sebagaimana tercantum dalam tabel berikut ini.

Tabel 1

Aktivitas yang Berkaitan dengan Kegiatan Kelisanan dan literasi

\begin{tabular}{|c|c|c|c|c|c|c|c|c|}
\hline \multirow{2}{*}{ No. } & \multicolumn{7}{|c|}{ FREKUENSI } & $\begin{array}{c}\text { Total } \\
(\%)\end{array}$ \\
\cline { 3 - 9 } & AKTIVITAS & \multicolumn{7}{|c|}{} \\
\cline { 3 - 10 } & 1 & 2 & 3 & 4 & 5 & 6 & \\
& & $(\%)$ & $(\%)$ & $(\%)$ & $(\%)$ & $(\%)$ & \\
\hline
\end{tabular}




\begin{tabular}{|c|c|c|c|c|c|c|c|c|}
\hline \multirow[t]{9}{*}{1} & $\begin{array}{l}\text { Pemanfaatan waktu sehari- } \\
\text { hari: }\end{array}$ & & & & & & & \\
\hline & $\begin{array}{l}\text { a. Menghadiri dan } \\
\text { mengerjakan tugas } \\
\text { perkuliahan }\end{array}$ & 72 & 21 & 4 & 3 & 0 & 0 & 100 \\
\hline & b. Bekerja mencari uang & 7 & 19 & 34 & 19 & 21 & 0 & 100 \\
\hline & $\begin{array}{l}\text { c. Mengejakan pekerjaan } \\
\text { rumah }\end{array}$ & 30 & 37 & 28 & 5 & 0 & 0 & 100 \\
\hline & $\begin{array}{l}\text { d. Berbincang-bincang/ } \\
\text { bercakap-cakap dengan } \\
\text { keluarga/ teman }\end{array}$ & 36 & 48 & 10 & 6 & 0 & 0 & 100 \\
\hline & e. Membaca & 6 & 41 & 42 & 11 & 0 & 0 & 100 \\
\hline & f. Menulis & 5 & 23 & 41 & 30 & 1 & 0 & 100 \\
\hline & $\begin{array}{l}\text { g. Menonton TV atau } \\
\text { browsing internet }\end{array}$ & 10 & 51 & 31 & 8 & 0 & 0 & 100 \\
\hline & $\begin{array}{l}\text { h. Berjalan-jalan atau } \\
\text { mengunjungi keluarga/ } \\
\text { teman }\end{array}$ & 2 & 40 & 42 & 16 & 0 & 0 & 100 \\
\hline 2 & \multicolumn{8}{|c|}{ Tujuan atau keperluan melakukan aktivitas berbincang-bincang/ bercakap-cakap: } \\
\hline & $\begin{array}{l}\text { a. Berbagi pendapat } \\
\text { tentang masalah } \\
\text { pribadi/keluarga }\end{array}$ & 13 & 34 & 30 & 21 & 2 & 0 & 100 \\
\hline & $\begin{array}{l}\text { b. Membahas pelajaran/ } \\
\text { masalah kuliah }\end{array}$ & 7 & 45 & 40 & 8 & 0 & 0 & 100 \\
\hline & $\begin{array}{c}\text { c. Sekedar bergaul dan } \\
\text { kumpul-kumpul dengan } \\
\text { keluarga/ teman }\end{array}$ & 18 & 46 & 30 & 6 & 0 & 0 & 100 \\
\hline & $\begin{array}{l}\text { d. Menggunjing teman/ } \\
\text { orang lain }\end{array}$ & 0 & 8 & 28 & 49 & 15 & 0 & 100 \\
\hline \multirow[t]{4}{*}{3} & \multicolumn{8}{|c|}{$\begin{array}{l}\text { Cara atau media yang digunakan dalam berbincang/ bercaka-cakap dengan anggota } \\
\text { keluarga/teman: }\end{array}$} \\
\hline & a. Langsung tatap muka & 41 & 49 & 8 & 2 & 0 & 0 & 100 \\
\hline & b. Melalui telepon & 8 & 32 & 40 & 15 & 5 & 0 & 100 \\
\hline & $\begin{array}{l}\text { c. Melalui jejaring sosial di } \\
\text { internet }\end{array}$ & 9 & 20 & 44 & 25 & 2 & 0 & 100 \\
\hline \multirow[t]{4}{*}{4} & \multicolumn{8}{|c|}{ Tujuan atau keperluan melakukan aktivitas membaca: } \\
\hline & $\begin{array}{l}\text { a. Memenuhi tugas kuliah } \\
\text { dari dosen }\end{array}$ & 30 & 50 & 19 & 1 & 0 & 0 & 100 \\
\hline & $\begin{array}{l}\text { b. Mencari informasi dan } \\
\text { menambah pengetahuan }\end{array}$ & 16 & 61 & 20 & 3 & 0 & 0 & 100 \\
\hline & c. Mengisi waktu luang & 10 & 33 & 44 & 13 & 0 & 0 & 100 \\
\hline \multirow[t]{7}{*}{5} & \multicolumn{8}{|c|}{ Jenis atau sumber bacaan yang dipilih: } \\
\hline & a. Buku literatur & 9 & 28 & 50 & 11 & 2 & 0 & 100 \\
\hline & b. Buku karya sastera & 11 & 39 & 28 & 17 & 5 & 0 & 100 \\
\hline & $\begin{array}{l}\text { c. Majalah, Koran dan } \\
\text { bacaan popular lainnya }\end{array}$ & 11 & 35 & 43 & 10 & 1 & 0 & 100 \\
\hline & $\begin{array}{l}\text { d. Bahan bacaan ilmiah di } \\
\text { internet }\end{array}$ & 9 & 30 & 46 & 14 & 1 & 0 & 100 \\
\hline & $\begin{array}{c}\text { e. Bahan bacaan popular/ } \\
\text { hiburan di internet }\end{array}$ & 15 & 41 & 25 & 14 & 5 & 0 & 100 \\
\hline & f. $\quad$ Lain-lain & 8 & 15 & 31 & 19 & 5 & 22 & 100 \\
\hline
\end{tabular}




\begin{tabular}{|c|c|c|c|c|c|c|c|c|}
\hline \multirow[t]{8}{*}{6} & \multicolumn{8}{|c|}{ Tujuan atau keperluan melakukan aktivitas menulis: } \\
\hline & $\begin{array}{c}\text { Memenuhi tugas kuliah } \\
\text { dari dosen }\end{array}$ & 41 & 46 & 13 & 0 & 0 & 0 & 100 \\
\hline & $\begin{array}{c}\text { b. Mencatat hal-hal penting } \\
\text { agar dapat diingat } \\
\text { dalam jangka panjang }\end{array}$ & 21 & 50 & 23 & 5 & 1 & 0 & 100 \\
\hline & $\begin{array}{l}\text { Mencatat semua } \\
\text { kejadian sehari-hari } \\
\text { yang dialami }\end{array}$ & 2 & 12 & 33 & 38 & 15 & 0 & 100 \\
\hline & $\begin{array}{l}\text { d. Menyalurkan bakat/ } \\
\text { hobi di bidang sastra }\end{array}$ & 5 & 15 & 33 & 28 & 19 & 0 & 100 \\
\hline & $\begin{array}{c}\text { e. Menyampaikan pesan } \\
\text { kepada orang lain }\end{array}$ & 8 & 27 & 34 & 24 & 7 & 0 & 100 \\
\hline & $\begin{array}{c}\text { f. Berbagi pengetahuan } \\
\text { dengan orang lain }\end{array}$ & 4 & 27 & 41 & 25 & 3 & 0 & 100 \\
\hline & g. Mengisi waktu luang & 7 & 20 & 36 & 30 & 6 & 1 & 100 \\
\hline \multirow[t]{4}{*}{7} & \multicolumn{8}{|c|}{ Media yang digunakan dalam aktivitas menulis: } \\
\hline & a. Kertas atau buku & 27 & 36 & 28 & 9 & 0 & 0 & 100 \\
\hline & 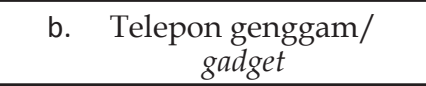 & 15 & 37 & 29 & 14 & 5 & 0 & 100 \\
\hline & c. Computer dan internet & 22 & 46 & 21 & 9 & 2 & 0 & 100 \\
\hline \multirow[t]{6}{*}{8} & \multicolumn{8}{|c|}{ Aktivitas yang dilakukan untuk mengisi waktu luang: } \\
\hline & $\begin{array}{c}\text { a. Berbincang-bincang/ } \\
\text { ngobrol }\end{array}$ & 18 & 48 & 29 & 5 & 0 & 0 & 100 \\
\hline & b. Membaca/ menulis & 10 & 30 & 51 & 9 & 0 & 0 & 100 \\
\hline & c. Main game & 6 & 25 & 30 & 35 & 4 & 0 & 100 \\
\hline & $\begin{array}{l}\text { d. Nonton TV dan jalan- } \\
\text { jalan }\end{array}$ & 12 & 39 & 28 & 20 & 1 & 0 & 100 \\
\hline & $\begin{array}{c}\text { Mengerjakan pekerjaan } \\
\text { bermanfaat lainnya }\end{array}$ & 11 & 46 & 32 & 9 & 0 & 2 & 100 \\
\hline \multirow[t]{6}{*}{9} & \multicolumn{8}{|c|}{ Aktivitas yang dilakukan ketika berada di tempat-tempat umum: } \\
\hline & $\begin{array}{c}\text { a. Berbincang-bincang/ } \\
\text { ngobrol }\end{array}$ & 18 & 49 & 31 & 2 & 0 & 0 & 100 \\
\hline & b. Membaca/ menulis & 4 & 19 & 43 & 31 & 3 & 0 & 100 \\
\hline & $\begin{array}{l}\text { c. Main game atau kotak } \\
\text { katik telepon genggam }\end{array}$ & 7 & 49 & 31 & 13 & 0 & 0 & 100 \\
\hline & d. Browsing internet & 9 & 28 & 41 & 20 & 2 & 0 & 100 \\
\hline & e. Lain-lain & 5 & 19 & 34 & 19 & 6 & 17 & 100 \\
\hline \multirow[t]{5}{*}{10} & \multicolumn{8}{|c|}{ Aktivitas yang dilakukan ketika menggunakan internet: } \\
\hline & $\begin{array}{c}\text { a. Bermain facebook/twitter } \\
\text { atau chatting }\end{array}$ & 24 & 46 & 20 & 10 & 0 & 0 & 100 \\
\hline & $\begin{array}{c}\text { b. Browsing materi kuliah } \\
\text { dan bahan-bahan } \\
\text { bacaan lain }\end{array}$ & 10 & 54 & 35 & 1 & 0 & 0 & 100 \\
\hline & c. Blogging & 4 & 8 & 30 & 38 & 20 & 0 & 100 \\
\hline & d. Lain-lain & 5 & 15 & 27 & 26 & 7 & 20 & 100 \\
\hline \multirow[t]{4}{*}{11} & \multicolumn{8}{|c|}{ Alasan kecenderungan melakukan aktivitas kelisanan daripada aktivitas literasi: } \\
\hline & $\begin{array}{c}\text { a. Mempererat hubungan } \\
\text { kekeluargaan/ } \\
\text { pertemanan }\end{array}$ & 33 & 53 & 14 & 0 & 0 & 0 & 100 \\
\hline & $\begin{array}{l}\text { b. Menyampaikan dan } \\
\text { memperoleh informasi }\end{array}$ & 26 & 52 & 22 & 0 & 0 & 0 & 100 \\
\hline & $\begin{array}{l}\text { c. Menambah } \\
\text { pengetahuan dan } \\
\text { pengalaman }\end{array}$ & 19 & 49 & 30 & 2 & 0 & 0 & 100 \\
\hline
\end{tabular}




\begin{tabular}{|l|l|l|l|l|l|l|l|l|}
\hline & d. $\begin{array}{c}\text { Bermanfaat untuk } \\
\text { mengisi waktu luang }\end{array}$ & 15 & 45 & 31 & 9 & 0 & 0 & 100 \\
\hline
\end{tabular}

Keterangan:

Frekuensi :

1. : Selalu

2. : sering

3. : kadang-kadang

4. : jarang

5. : tidak pernah

6. : tidak memberi jawaban

Berdasarkan hasil perhitungan frekuensi kegiatan mahasiswa berkenaan dengan aktivitas kelisanan dan literasi, baik di lingkungan kampus maupun di luar kampus dapat diterangkan beberapa hal penting sebagaimana uraian berikut ini. Pertama, diketahui bahwa sebagian besar mahasiswa FKIP Untan (72\%) dari jumlah responden adalah mahasiswa murni dengan kewajiban utama adalah menghadiri perkuliahan. Dalam mengemban tugas sebagai mahasiwa, seharusnya tugas utama mahasiswa adalah melakukan aktivitas literasi. Namun demikian, hanya sebagian mahasiswa (41\%) yang menyatakan sering membaca. Bahkan hanya $6 \%$ responden yang menyatakan selalu membaca sebagai bagian dari kegiatan hari-hari mereka. Demikian pula dengan kegiatan menulis, hanya sebagian kecil (5\%) dari mereka yang menyatakan selalu menulis dan yang sering hanya sejumlah 23\%. Selebihnya hanya kadang-kadang dan bahkan jarang (41\% dan 30\%). Data ini menunjukkan bahwa kegiatan literasi belum sepenuhnya merupakan aktivitas rutin bagi mahasiswa.

Sebaliknya, aktivitas kelisanan dalam bentuk bincang-bincang atau bercakapcakap dengan sesama mahasiswa atau dengan anggota keluarga adalah lebih dominan. Ada sejumlah 36\% dari mereka yang menyatakan selalu bercakap-cakap untuk mengisi waktu dan ada sejumlah $48 \%$ yang menyatakan sering. Sementara yang menyatakan kadang-kadang ada sejumlah 10\% dan yang jarang melakukan aktivitas kelisanan ada sebanyak (6\%). Dengan kata lain, aktivitas kelisanan masih mendominasi aktivitas mahasiswa sehari-hari dibandingkan dengan aktivitas literasi.

Adapun alasan utama mengapa mereka lebih memilih aktivitas kelisanan daripada aktivitas literasi ialah untuk berbagi berbagai persoalan atau urusan, baik urusan belajar atau kuliah, urusan pribadi dan keluarga dan untuk keperluan pergaulan sosial. Bahkan sebagian (28\%) darimereka mengatakan bahwakesempatan berbincang-bincang ini dilakukan kadang-kadang untuk keperluan menggunjing orang lain. Adapun cara atau media yang digunakan dalam berbincang-bincang ini hampir selalu melalui pertemuan langsung tatap muka. Selain secara tatap muka langsung, mereka juga sering atau kadang-kadang berbincang-bincang melalui telepon atau jejaring sosial di internet.

Kegiatan berbincang-bincang tidak hanya dilakukan di rumah atau di lingkungn kampus, melainkan juga di tempat-tempat umum seperti di kantin dan 
di tempat-tempat berkumpul lainnya atau bahkan ketika berada di jalan. Untuk mengisi waktu luang sebagian besar mahasiswa (66\%) hampir selalu memilih menggunakannya untuk berbincang-bincang daripada untuk membaca, hanya $40 \%$ dari mereka yang menggunakan waktu luangnya untuk membaca. Bahkan ketika mereka berada sendiri dengan telepon genggam atau dengan laptop yang difasilitasi dengan internet, yang mereka lakukan hampir selalu (70\%) untuk berbincangbincang lewat jejaring sosial seperti facebook, twitter dan sejenisnya. Meskipun demikian, sebagian dari mereka (64\%) juga sering memanfaatkan fasilitas internet ini untuk keperluan browsing atau mengunduh materi-materi perkuliahan atau bahan-bahan bacaan lainnya. Sementara itu, masih sedikit dari mereka (18\%) yang sering memanfaatkan fasilitas internet untuk keperluan menulis.

Sebagaimana telah dikatakan bahwa status mahasiswa tidak dapat dipisahkan dari tugas-tugas literasi (literacy). Namun pada kenyataanya hanya 47\% mahasiswa yang hampir selalu memanfaatkan waktu sehari-hari untuk membaca dan hanya 28\% dari mereka yang hampir selalu menulis sebagai kegiatan sehari-hari. Sementara hanya $42 \%$ dari mereka hanya kadang-kadang mengisi waktu sehari-hari untuk melakukan aktivitas literasi. Adapun aktivitas literasi ini mereka lakukan utamanya hampir selalu untuk tujuan atau keperluan memenuhi tugas-tugas perkuliahan yang diberikan oleh dosen. Sedangkan untuk keperluan pribadi seperti mencatat kejadian penting sehari-hari hanya dilakukan oleh $14 \%$ dari mereka dan untuk menyalurkan hobi hanya dilakukan oleh 20\% dari mereka. Sementara itu, ada 35\% dari mereka yang hampir selalu melakukan aktivitas menulis untuk keperluan menyampaikan pesan kepada orang lain dan untuk keperluan mengisi waktu luang (27\%). Pada umumnya media yang digunakan untuk menulis adalah dengan menggunakan media kertas atau buku (63\%) dan komputer (68\%).

Dibanding kegiatan membaca dan menulis, para mahasiswa cenderung memilih aktivitas kelisanan daripada literasi. Pilihan ini dilakukan dengan alasan bahwa aktivitas kelisanan lebih efektif untuk mempererat hubungan sosial kekeluargaan/pertemanan (86\%), untuk menyampaikan dan memperoleh informasi $(78 \%)$, untuk menambah pengetahuan (68\%) dan lebih menyenangkan untuk mengisi waktu luang (60\%).

\section{Hasil Focused Group Discussion (FGD)}

Selain dari hasil data pengamatan dengan catatan lapangan dan data laporan diri dari hasil kuesioner, sebagaimana telah dideskripsikan di atas, berikut ini akan diuraikan data yang diperoleh dari hasil diskusi terfokus atau yang disebut dengan focused group discussion (FGD). Diskusi ini dilakukan dengan sekelompok mahasiswa yang terdiri dari 10 orang yang mewakili 100 orang mahasiswa yang sebelumnya telah ditetapkan sebagai subjek penelitian ini. Data yang diperoleh melalui teknik ini secara umum memberikan konfirmasi terhadap data yang telah diperoleh sebelumnya.

Pada umumnya, mahasiswa tersebut membenarkan bahwa aktivitas seharihari mereka lebih didominasi oleh aktivitas komunikasi kelisanan daripada literasi. 
Aktivitas kelisanan ini tidak hanya mereka lakukan kepada sesama anggota keluarga, teman, atau kenalan ketika saling berkumpul atau ketika mereka saling bertemu tatap muka langsung tetapi juga ketika mereka terpisah oleh jarak dan waktu. Komunikasi lisan diantara mereka tetap dapat dilakukan melalui media telepon (telepon genggam) atau internet. Komunikasi lisan jarak jauh ini dapat digantikan dengan komunikasi secara tertulis. Contohnya dengan menyampaikan pesan menggunakan telepon genggam melalui pesan singkat (SMS), pos-el, dan obrolan melalui program-program chatting atau program jejaring sosial lain yang terdapat di internet. Meskipun disampaikan secara tertulis, sebenarnya bentuk komunikasi yang demikian ini merupakan aktivitas kelisanan atau yang disebut dengan kelisanan sekunder.

Aktivitas kelisanan ini juga dilakukan secara formal dalam rangka memenuhi tugas-tugas perkuliahan, misalnya untuk berinteraksi di dalam proses perkuliahan, diskusi dan presentasi di kelas, serta untuk latihan atau praktik mengajar, forum seminar dan ujian lisan mata kuliah serta ujian sidang skripsi. Selain itu, aktivitas kelisanan formal ini juga dilakukan oleh mahasiswa dalam kegiatan rapat-rapat organisasi kemahasiswaan, terutama oleh mereka yang aktif di organisasi tersebut.

Sementara itu, pada umumnya, aktivitas literasi yang sesungguhnya hanya dilakukan untuk keperluan memenuhi tugas-tugas perkuliahan. Sebagai contoh, untuk menulis makalah dari mata kuliah yang sedang dipelajari, menjawab soalsoal baik untuk tugas terstrukur maupun ujian-ujian, membuat laporan hasil kerja praktek laboratorium, laporan hasil kerja praktek lapangan, membuat rangkuman hasil membaca buku atau artikel, menyiapkan powerpoint untuk presentasi di kelas dan untuk memenuhi tugas akhir skripsi. Aktivitas membaca dianggap pekerjaan yang melelahkan dan membosankan, terutama membaca bahan perkuliahan. Demikian pula menulis, sangat sulit untuk dilakukan. Beruntung ada banyak materi yang dapat diakses melalui internet sehingga dapat menjadi contoh dan bahkan kadang-kadang mereka tinggal ambil bahan-bahan tulisan dari internet untuk tugas-tugas kuliah.

Dalam kelompok partisipan diskusi ini tidak ditemukan mahasiswa yang memiliki hobi menulis kecuali untuk keperluan memenuhi tugas perkuliahan, sebagaimana telah diuraikan sebelumnya. Selain itu, aktivitas menulis dilakukan untuk menyampaikan pesan-pesan lewat telepon genggam atau melalui jejaring sosial yang terdapat di internet atau hanya untuk mengungkapkan pikiran, pendapat dan perasaan lewat jejaring sosial tersebut. Lagi-lagi hal ini mengkonfirmasi bahwa aktivitas menulis yang mereka lakukan pada dasarnya hanya menggantikan aktivitas kelisanan yang biasanya dilakukan secara langsung tatap muka.

Selain untuk aktivitas formal perkuliahan, mereka menghabiskan waktu untuk berbagai keperluan pribadi, baik di dalam lingkungan kampus atau di luar kampus. Dalam pada itu, hampir semua dari mereka lebih memilih menghabiskan waktunya dengan aktivitas kelisanan daripada menulis. Ketika sedang tidak menghadiri perkuliahan, tempat berkumpul yang mereka pilih adalah kantin kampus, taman-taman di sekitar kampus atau di ruang-ruang terbuka lainnya. Di 
tempat-tempat inilah mereka biasanya menghabiskan waktu bersama, baik untuk mengerjakan pekerjaan kuliah seperti membaca, menulis atau berdiskusi atau hanya sekedar melepaskan lelah sambil berbincang-bincang serta bergurau dengan sesama teman. Bahkan ketika berada sendiri dengan laptop atau handphone, masingmasing mereka masih tetap dapat berkomunikasi dengan orang lain di luar sana. Dalam mengisi waktu luang ini aktivitas kelisanan masih menjadi pilihan utama dibanding dengan aktivitas literasi. Aktivitas serupa juga berlangsung di rumah atau di kediaman mereka.

Adapun alasan mengapa aktivitas kelisanan lebih disukai dibanding aktivitas literasiadalah karenaaktivitas ini dianggaplebihmengasyikkanatau menyenangkan. Dengan itu mereka dapat bergaul, memiliki banyak teman, menjaga hubungan baik, dapat berbagi berbagai persoalan. Mereka menganggap bahwa aktivitas berbincang-bincang atau bercakap-cakap secara tatap muka dapat menciptakan keasyikan atau kesenangan atau kenikmatan bersama-sama sedangkan menulis hanya dapat dinikmati sendiri. Bahkan apabila mereka mendapatkan teman atau anggota keluarga yang tidak banyak bicara, mereka dianggap orang-orang yang kurang asyik atau kurang menyenangkan untuk dijadikan teman baik.

Namun demikian, apa yang terjadi di kelas ketika interaksi perkuliahan berlangsung yang terjadi adalah sebaliknya. Mahasiswa lebih banyak diam dan mendengar. Hal ini karena memang lebih sering dosen yang mendominasi pembicaraan pada saat perkuliahan berlangsung. Mereka hanya berbicara apabila diminta atau diperintahkan melalui pertanyaan-pertanyaan yang diajukan oleh dosen atau ketika mereka harus mempresentasikan sesuatu di depan kelas. Banyak di antara mereka mengaku enggan berbicara dengan inisiatif sendiri seperti bertanya dan menyampaikan pendapat di forum kelas, kecuali terpaksa dan diminta oleh dosen. Ini disebabkan adanya rasa kurang percaya diri, malu, takut salah, takut ditertawakan dan lain-lain. Berdasarkan pengamatan di kelas hal ini memang demikian adanya, di mana biasanya hanya beberapa mahasiswa saja yang selalu aktif bertanya atau menyampaikan pendapat pada saat berinteraksi di kelas tersebut kecuali apabila mereka ditugaskan untuk itu. Untuk mampu tampil berbicara dengan baik di kelas memerlukan keberanian, kepercayaan diri, dan persiapan yang sangat baik. Oleh sebab itu, sebagian dari mereka ketika melakukan presentasi lisan belum dapat melakukan sebagaimana layaknya bertutur lisan, melainkan hanya membaca teks dengan bersuara atau yang disebut dengan kelisanan tekstual.

Sebagaimana diketahui, pada dekade belakangan ini media komunikasi elektronik dengan berbagai fasilitas kemudahannya telah tumbuh berkembang dengan pesat sehingga dengan menggunakannya kita tetap dapat berkomunikasi, baik lisan maupun tertulis tanpa harus dibatasi oleh ruang dan waktu. Dalam kaitan ini, kampus FKIP telah menyediakan fasilitas internet sehingga memungkinkan mahasiswa untuk mengakses berbagai fasilitas yang ada di internet. Selain itu, hampir semua mahasiswa mempunyai telepon genggam, laptop serta berbagai macam gadget dengan berbagai fitur dengan fasilitas internet. Keberadaan perangkat tersebut dapat menggantikan aktivitas komunikasi langsung tatap muka menjadi 
komunikasi jarak jauh langsung ataupun tunda, lisan maupun tulis. Dalam hal ini, kembali mahasiswa membenarkan bahwa penggunaan internet di kawasan kampus tidak semata-mata digunakan untuk keperluan perkuliahan tetapi juga untuk keperluan pribadi, baik untuk kepentingan berkomunikasi jarak jauh maupun untuk mendapatkan hiburan atau kesenangan-kesenangan lainnya, misalnya untuk bermain game, facebook, twitter, dan program jejaring sosial lain dimana mereka dapat melakukan chatting atau komunikasi jarak jauh.

Sementara itu, untuk memenuhi tugas-tugas perkuliahan, keberadaan fasilitas internet ini mereka manfaatkan untuk mendapatkan bahan-bahan berupa e-book, artikel dan bahan-bahan bacaan lain untuk memenuhi tugas-tugas yang diberikan oleh dosen. Tugas-tugas tersebut membuat mereka harus melakukan aktivitas membaca dan menulis. Lebih lanjut, menurut mereka, dengan adanya bahan-bahan relevan yang tersedia di internet membuat mereka tidak harus repot-repot membaca secara intensif dan membuat tulisan dengan susah payah apabila diminta membuat karya tulis dan semacamnya. Dengan ketersediaan bahan-bahan di internet tersebut yang perlu mereka lakukan hanya dengan cara mengubahsuai menurut keperluan. Bahkan diakui kadang-kadang untuk memenuhi tugas tersebut, terutama apabila mendesak, mereka hanya menjiplak (copy and paste) persis seperti apa yang tersedia di internet tersebut.

Meskipun beberapa program internet menyediakan kesempatan mahasiswa untuk menulis secara kreatif, seperti blogger, wordpress, livejournal, facebook, dan lainlain tetapi hanya sedikit mahasiswa yang telah memanfaatkan fasilitas tersebut untuk menulis. Terdapat satu mata kuliah dari salah satu program studi yang mengharuskan mereka untuk menulis melalui salah satu program internet tersebut sebagai tugas dan persyaratan kelulusan pada mata kuliah tersebut.

\section{Temuan dan Diskusi}

Dari hasil uraian data di atas dapat dikemukakan beberapa temuan penting antara lain berupa fakta-fakta berikut ini. Pertama, kegiatan kelisanan masih mendominasi aktivitas mahasiswa baik di lingkungan kampus maupun di luar kampus. Aktivitas kelisanan ini tidak hanya dilakukan secara langsung tatap muka melainkan sudah dapat tergantikan oleh media elektronik sehingga memungkinkan kegiatan kelisanan tidak terbatas oleh ruang dan waktu.

Fakta kedua, aktivitas literasi pada umumnya dilakukan hanya untuk memenuhi tugas-tugas perkuliahan. Hanya sedikit sekali yang melakukan aktivitas literasi ini untuk kepentingan pribadi sehari-hari atau untuk menyalurkan bakat meskipun telah tersedia berbagai media yang memungkinkan mahasiwa untuk berpartisipasi menulis secara kreatif. Adapun aktivitas menulis di luar keperluan tugas perkuliahan yang mereka lakukan pada umumnya masih merupakan pengganti aktivitas kelisanan yang disampaikan secara tertulis melalui media.

Fakta ketiga adalah mengenai alasan mengapa aktivitas kelisanan lebih mendominasi aktivitas sehari-hari mahasiswa baik di dalam maupun di luar kampus daripada kegiatan literasi. Adapun alasan tersebut adalah bahwa aktivitas 
kelisanan lebih efektif dan menyenangkan dalam menjalin hubungan sosial. Dengan kata lain, aktivitas kelisanan mengandung nilai-nilai kebersamaan, memelihara solidaritas, kesantunan serta kenyamanan dalam berkomunikasi.

Dalam pada itu, aktivitas kelisanan formal dan akademik di lingkungan kampus, khususnya di dalam kelas adalah lebih disebabkan karena penugasan oleh dosen. Hal ini bergantung kepada desain pembelajaran yang dikembangkan oleh dosen dalam proses perkuliahan. Masih sedikit aktivitas kelisanan yang dilakukan atas inisiatif mahasiswa sendiri seperti bertanya, menyampaikan pendapat atau kritik dalam interaksi di kelas. Ini disebabkan karena mereka belum terbiasa dengan kelisanan akademik atau tekstual sehingga mereka kurang percaya diri, takut, malu, dan perasaan tidak nyaman lainnya karena semua performa mereka berada dalam penilaian dosen. Disamping itu, model-model pembelajaran yang diterapkan pada umumnya mengharuskan dosen atau pengajar untuk mendominasi aktivitas kelisanan di dalam kelas. .

Sementara itu, fakta berikutnya menunjukkan bahwa aktivitas literasi dianggap kurang menyenangkan, hanya mendatangkan keasyikan sendiri, tidak bersama-sama. Kegiatan membaca dianggap melelahkan. Demikian pula menulis, dianggap aktivitas yang sulit untuk dikerjakan dan membosankan, terutama ketika harus mengemukakan ide dan pikiran sendiri. Menulis hanya terpaksa dilakukan untuk memenuhi tugas-tugas perkuliahan yang diwajibkan kepada mereka. Dengan demikian, aktivitas literasi ini menyiratkan makna atau nilai perseorangan atau individualistik, sesuatu yang sulit dan membosankan.

Berdasarkan temuan-temuan tersebut dapat dikemukakan disini bahwa aktivitas kelisanan masih menjadi bagian yang terpisahkan dari kehidupan mahasiswa. Ini disebabkan latar belakang etnik mahasiswa tersebut adalah dari komunitas etnik Melayu dengan identitas kelisanan. Aktivitas kelisanan ini merupakan budaya yang tidak dapat dipisahkan dari komunitas etnik Melayu karena memiliki makna-makna sosial yang positif seperti kebersamaan, kepedulian, solidaritas, kesantunan serta kenyamanan dalam menjalin hubungan sosial. Mereka yang berkongsi makna-makna tersebut dan memeliharanya akan menjadi pribadipribadi yang peduli dengan sesama, memiliki toleransi tinggi, mudah bergaul dan dapat memelihara hubungan baik dengan sesame teman atau sesama anggota keluarga atau masyarakat.

Namun demikian, dalam komunikasi atau interaksi formal pada perkuliahan, praktik kelisanan ini tidak selalu berlangsung secara spontan atas inisiatif mahasiswa, sebagaimana halnya dalam percakapan informal. Aktivitas berbicara di kelas terjadi karena adanya desain untuk itu sesuai dengan strategi atau modelmodel pembelajaran yang diterapkan oleh dosen. Aktivitas kelisanan yang terjadi di forum kelas adalah aktivitas kelisanan formal atau tektual berbentuk Tanya jawab, diskusi dan peresentasi.

Sementara itu, aktivitas literasi oleh mahasiswa belum menjadi bagian kegiatan rutin sebagai kebutuhan dalam kehidupan di luar kegiatan kampus. Aktivitas literasi ini hanya mereka lakukan apabila diwajibkan atas mereka berkaitan dengan tugas- 
tugas perkuliahan. Dengan demikian, aktivitas literasi ini belum menjadi budaya bagi mahasiswa. Padahal kegiatan literasi merupakan tuntutan dalam kehidupan mahasiswa sehingga seharusnya sudah menjadi budaya yang tak terpisahkan dari kehidupan mereka. Budaya literasi (literate culture) ini sudah sepatutnya untuk terus ditumbuhkembangkan di kalangan mahasiswa karena ini merupakan tuntutan tidak hanya kepada mahasiswa melainkan kepada seluruh civitas akademika di lingkungan kampus. Sebagaiman telah dijelaskan dalam bab sebelumnya, budaya literasi dapat membangun karakter pribadi seseorang dengan sifat-sifat atau ciriciri pribadi yang terpelajar, cerdas, mandiri, selalu berfikir logis dan kritis serta kreatif dan inovatif, sebagaimana layaknya pribadi seorang ilmuwan.

Dengan demikian, karakter pribadi mahasiwa yang dibawa oleh mereka karena latar belakang asal etnik dengan budaya kelisanan yang mereka miliki tidak lah buruk melainkan dapat menjadi suatu kearifan karena dalam budaya tersebut menyiratkan makna-makna sosial yang positif serta dapat membangun nilainilai kepribadian yang positif pula. Oleh sebab itu, budaya tersebut tetap dapat dipertahankan. Namun demikian, karena budaya literasi merupakan keutamaan dalam kehidupan dunia kampus, keduanya harus dapat diakomodasi dan diselaraskan melalui pilihan strategi dan model-model pembelajaran yang relevan. Salah satunya adalah pendekatan CTL. Sebagaimana telah pula dijelaskan diatas, pendekatan CTL dengan variasi model-model pembelajarannya dapat memfasilitasi atau mengakomodasi aktivitas kelisanan dan literasi secara bersamaan. Melalui proses pembelajaran berdasarkan pendekatan ini secara berkelanjutan, mahasiswa akan tetap dapat mengekalkan nilai-nilai yang sebelumnya selalu mereka kongsi dari budaya kelisanan yaitu kebersamaan atau kerjasama, solidaritas, kepedulian sosial, dan saling ketergantungan. Bersamaan dengan itu pula, mereka akan dapat menumbuhkembangkan budaya literasi sebagai representasi dari budaya keilmuan yang senantiasa mengembangkan kepribadian berdasarkan nilai-nilai cerdas, penuh inisiatif, mandiri, berfikir logis, kritis, kreatif, dan inovatif serta berdaya saing.

\section{KESIMPULAN}

Untuk menjawab pertanyaan yang diajukan dalam penelitian ini berikut akan disampaikan hasil kesimpulan dan saran yang diambil berdasarkan hasil analisis data, temuan dan diskusi.

Berdasarkan hasil analisis data, temuan dan diskusi, seperti telah diuraikan di atas dapat disimpulkan beberapa poin sebagai berikut:

Pertama, aktivitas kelisanan masih mendominasi baik di dalam dan di luar kampus. Aktivitas kelisanan ini pada umumnya berlangsung dalam komunikasi informal dalam obrolan atau bincang-bincang di kelas di luar jam kuliah, di tamantaman, di kantin-kantin, dan di tempat-tempat terbuka lainnya di lingkungan kampus. Demikian pula ketika mereka berada di rumah atau di tempat-tempat umum lainnya. Komunikasi lisan ini tidak hanya berlangsung secara tatap muka tetapi juga dalam jarak jauh dan tidak langsung melalui media komunikasi seperti telepon dan internet. Sementara itu, dalam komunikasi formal dalam perkuliahan, 
kelisanan ini pada umumnya berlangsung disebabkan oleh desain model pembelajaran yang diterapkan oleh dosen, dimana dalam model-model tersebut mengharuskan mahasiswa untuk berkomunikasi lisan, seperti bertanya jawab, berdiskusi dan peresentasi.

Kedua, dapat disimpulkan bahwa aktivitas literasi juga berlangsung dalam kegiatan sehari-hari mahasiswa. Namun demikian, kegiatan itu masih terbatas untuk keperluan memenuhi tugas-tugas perkuliahan yang diberikan oleh dosen, khususnya aktivitas literasi yang bersifat akademik. Meskipun fasilitas internet memberi peluang bagi mahasiswa untuk mengembangkan budaya literasi formal dan akademik, mereka belum memanfaatkan fasilitas tersebut secara maksimal. Aktivitas literasi yang mereka kembangkan masih terbatas pada yang bersifat informal dan hanya sebagai pengganti aktivitas kelisanan (kelisanan sekunder). Contohnya menulis pesan singkat (SMS) lewat telepon genggam atau chatting lewat program-program jejaring sosial yang tersedia di internet. Bahkan masih sedikit di antara mereka yang gemar membaca bahan-bahan lain di luar materi perkuliahan, menulis buku harian, mencatat kejadian-kejadian penting atau untuk menyalurkan hobi.

Ketiga, budaya kelisanan masih menjadi bagian yang tak terpisahkan dari kepribadian mahasiswa sebagai representasi dari komunitas etnik Melayu yang memiliki budaya tersebut. Ini disebabkan budaya tersebut mengandung nilai-nilai positif secara sosial seperti nilai-nilai kebersamaan atau kerjasama, kepedulian, solidaritas, kesantunan serta kenyamanan dalam berkomunikasi. Sementara itu, budaya literasi - meskipun masih dianggap aktivitas yang kurang menyenangkan dan masih sulit untuk dilakukan-merupakan budaya utama yang harus ditumbuhkembangkan dalam kehidupan kampus karena membawa nilai-nilai positif yang merepresentasikan kepribadian seseorang yang terpelajar, cerdas, penuh inisiatif, mandiri, berfikir logis, kritis, kreatif, dan inovatif serta berdaya saing, sebagaimana layaknya kepribadian seorang ilmuwan. Oleh sebab itu, kedua budaya tersebut dapat dikekalkan karena keduanya mengandung nilai-nilai yang positif.

Berikutnya, model-model pembelajaran yang tersedia sebagai strategi pembelajaran diantaranya adalah pendekatan CTL. Pendekatan ini menyediakan berbagai model pembelajaran yang dapat mengakomodasi dan menselaraskan kedua budaya tersebut sehingga dapat menciptakan pembiasaan aktivitas kelisanan akademik dan literasi secara bersamaan. Pada akhirnya, internalisasi nilai-nilai tersebut selama proses perkuliahan berlangsung dapat menumbuhkembangkan kepribadian mahasiswa sebagai seorang ilmuwan tanpa harus meninggalkan kepribadian yang berlatar belakang identitas etnik Melayu.

Oleh sebab itu, pendekatan CTL dapat disarankan untuk diterapkan karena melalui pendekatan tersebut aktivitas kelisanan formal dan aktivitas literasi dapat dilatih atau dipraktikkan secara bersamaan sehingga dapat membentuk budaya kelisanan (oral culture) dan literasi (literate culture) bagi mahasiswa secara bersamaan sehingga kepribadian ilmuwan dapat ditumbuhkembangkan dengan tetap 
mempertahankan identitas kepribadian yang didasarkankan pada budaya lokal. Berkaitan dengan ini, penelitian tindakan kelas dengan menggunakan pendekatan CTL dapat direkomendasikan sebagai penelitian lanjutan.

\section{DAFTAR PUSTAKA}

Bakran Suni. (2009). Demokrasi dan Budaya Politik Pilihan Raya Umum di Kalimantan Barat Indonesia. Tesis. Bangi: Institut Alam dan Tamadun Melayu Universiti Kebangsaan Malaysia.

Bogdan, Robert C., \& Biklen, Sari Knopp. (2007). Qualitative Research for Education: An Introduction to Theories and Methods (5 $5^{\text {th }}$ ed.). Boston: Pearson Education.

Cruickshank, Donald R. et al. (2006). The Act of Teaching (4 ${ }^{\text {th }}$ ed.). New York: McGrawHill.

Duranti, Alessandro. (1997). Linguistic Anthropology. United Kingdom: Cambridge University Press.

Effendy, Chairil. (2006). Sastra Sebagai Wadah Integrasi Budaya. Pontianak: STAIN Pontianak Press.

Ellis, Rod. (2009). Task-based Language Learning and Teaching. China: Oxford University Press.

Harmer, Jeremy. (2004). The Practice of English Language Teaching ( $3^{\text {rd }}$ ed.). Kuala Lumpur: Pearson Education.

Johnson, Elaine B. (2002). Contextual Teaching and Learning: What It Is and Why It's Here to Stay. California: Corwin Press.

Kramsch, Claire. (2008). Language and Culture. China: Oxford University Press.

Lantolf, James P. (2007). Intrapersonal Communication and Internalization in the Second Language Classroom. In Alex Kozulin et al (Eds.), Vygotsky's Educational Theory in Cultural Context (pp. 349-370). New York: Cambridge University Press.

Ong, Walter J. (1982). Orality and Literacy The Technologizing of The Word. New York: Methuen.

Panofsky, Carolyn P. (2007). The relations of Learning and Student Social Class: Toward Re-"socializing" Sociocultural Learning Theory. In Alex Kozulin et al (Eds.), Vygotsky's Educational Theory in Cultural Context (pp. 349-370). New York: Cambridge University Press.

Sudarso (2007). Mobilitas Sosial. In J. Dwi Narwoko \& Bagong Suyanto (ed.) Sosiologi: Teks Pengantar dan Terapan ( $2^{\text {nd }}$ ed.). Jakarta: Kencana.

Suwardi MS. (2008). Dari Melayu ke Indonesia Peranan Kebudayaan Melayu dalam Memperkokoh Identitas dan Jati Diri Bangsa. Yogyakarta: Penerbit Pustaka Pelajar.

Teeuw, A. (1994). Indonesia Antara Kelisanan dan Keberaksaraan. Jakarta: Pustaka Jaya. 
